\title{
The Effect of Plasmonic Nanoparticles and the Thickness of Anode Interface Layer on the Efficiency Enhancement of Organic Solar Cells
}

Neda Ahmadi ( $\sim$ ahmadiphysic@gmail.com )

Islamic Azad University Garmsar Branch https://orcid.org/0000-0002-6168-0121

\section{Research Article}

Keywords: Organic solar cells, Plasmonic nanoparticles, Transmission, Generation rate, Anode interface layer, Power absorp

Posted Date: May 19th, 2021

DOl: https://doi.org/10.21203/rs.3.rs-423127/v2

License: (9) This work is licensed under a Creative Commons Attribution 4.0 International License.

Read Full License 


\title{
The effect of plasmonic nanoparticles and the thickness of anode interface layer on the efficiency enhancement of organic solar cells
}

\author{
Neda Ahmadi * \\ Department of Basic Sciences, Garmsar Branch, Islamic Azad University, Garmsar, Iran
}

May 7, 2021

\begin{abstract}
We investigate the effect of nanoparticles (NPs) position on the optical parameters of organic solar cells (OSCs). We change the position of NPs inside the anode interface layer (AIL) and active layer and study the role of NPs position in light transmission, power absorption, short-circuit current density (Jsc), and maximum generation rate. We also use silver $(\mathrm{Ag})$ nanoparticles inside the anode interface layer and investigate the optical parameters. Moreover, we study the role of AIL thickness in light transmission and power absorption. We use finite-different timedomain (FDTD) method for all simulations. This study can be useful for new perspectives and light management in organic solar cells.

Keywords: Organic solar cells, Plasmonic nanoparticles, Transmission, Generation rate, Anode interface layer, Power absorption.
\end{abstract}

\footnotetext{
*E-mail: n.ahmadi@srbiau.ac.ir, ahmadiphysic@gmail.com
} 


\section{Introduction}

Photovoltaic technologies are the best solution for climate changes in order to using renewable and sustainable energy. For these reasons extensive effort have been concentrated on developing new generations of this technology such as Organic solar cells, Quantum dot solar cells, Perovskite solar cells $[1,2,3,4]$ etc. Organic solar cells are cheaper than current silicon-based technology and the process of manufacturing of them is easer than silicon-based solar cells. They also have the salient features such as light weight, flexibility and tunable transparency $[5,6,7]$ etc., even though, they have low power conversion efficiency.

Recent OSCs have over 10\% power conversion efficiency (PCE) based on single-junction devices. Single-junction terrestrial OSCs have reached an efficiency of $11.2 \pm 0.3$ under the global spectrum $\left(1000 \mathrm{w} / \mathrm{m}^{*} 2\right)$ at $25^{\circ} \mathrm{c}$ [8]. On the other hand tandem OSCs have achieved $10.6 \%$ PCE under standard test conditions [9]. These days, theoretical studies have shown that PCEs of tandem OSCs can achieve 15-20\% by optimizing the active layer properties and device architectures [10,11].

One of the promising way to increase the efficiency enhancement of solar cells is plasmonic nanoparticles $[15,16,17]$. For example in the previous work we investigated the effect of plasmonic nanoparticles on efficiency enhancement of thin film silicon solar cells [18]. We found that using metallic nanoparticles improve the efficiency of silicon-based solar cells because NPs create highly concentrated on near-field, increasing pathlength due to far-field scattering and wave guide coupling [11].

In previous studies we worked on optical properties of nanomaterials $[12,13,14]$. In this work we study the effect of plasmonic nanoparticles on OSCs. We have used Poly (3,4-ethylenedioxyt hiophene): poly (styrene sulfonate) (PEDOT:PSS) as an anode interface layer (AIL) and Poly (3-hexylthiophene) (P3HT) and [6,6 ]-Phenyl-C61-butyric acid methyl ester (PCBM) ( P3HT:PCBM) as an active layer. Nano particles are located at these layers and investigate the optical parameters. We have also optimized AIL thicknesses and study the effect of variation of thickness on power absorption and light transmission.

\section{Method and formalism}

In this article we use finite difference time domain (FDTD ) method solving Maxwell"s equations for our simulation. We investigated the effect of plasmonic nanoparticles on the efficiency of typical OSC with a photoactive layer of bilayer planar heterojunction which is sandwiched between two electrode.

The sunlight ranging is from 300 to $750 \mathrm{~nm}$. We use two kind of nanoparticles Ag and $\mathrm{Au}$ and compare the effects of them. The radius of these NPs is $30 \mathrm{~nm}$ and complex index $(\mathrm{n}, \mathrm{k})$ of $\mathrm{Ag}$ and $\mathrm{Au}$ were fitted from reference[19].

We use Al; a metal with low work function (WF), with dimensions: $\mathrm{X}=2, \mathrm{Y}=2, \mathrm{Z}=0.5$ $\mu m$ as cathode which was taken from reference [20] and zinc oxide (Zno) as cathode interface layer (CIL) with thickness $0.07 \mu \mathrm{m}$. Zinc oxide (Zno) is an inorganic n-type semiconductor is one of the best materials for metal oxide cathode interface layer because it has low cost, easy synthesis, non-toxic properties [21] etc., and this material was fitted from reference[22]. 
We use Indium tin oxide (ITO) as Anode was taken from reference [23] with thickness $\mathrm{Z}=0.178 \mu \mathrm{m}$.

Active layer is Poly (3-hexylthiophene) (P3HT) and [6,6 ]-PhenylC61-Butyric acid methyl ester (PCBM) ( P3HT:PCBM) were fitted from [24, 25]. The dimensions of active layer are : $\mathrm{X}=2, \mathrm{Y}=2$ and $\mathrm{Z}=0.193 \mu \mathrm{m}$.

Poly (3,4-ethylenedioxyt hiophene ): poly (styrene sulfonate) (PEDOT:PSS) is used as an anode interface layer to modify the ITO electrode and was fitted from [24].

\section{Result and Discussion}

\subsection{Gold ( $\mathrm{Au})$ NPs located inside Anode interface layer}

Light trapping in OGCs is a promising way to increase PCE. There are several techniques for light trapping in OSCs including of periodic nanostructures [26, 27, 28], diffraction grating [29, 30], metallic nanoparticles [31] and using grating and metallic nanoparticles $[32]$

metallic nanoparticles can enhance the absorption of light due to two mechanism. One of them is the increasing of forward scattering cross section and the second is a near field enhancement [33]. In this work we investigate the effect of NPs position on OSCs. Previous experimentally literatures have shown that metal NPs position is one of the most important factor for efficiency enhancement of OSCs $[10,34,17]$. The experimental results show that metal NPs are usually placed inside the AIL [35]. There are different fabrication methods such as electrodiposition [36], thin film evaporation [37] and chemical synthesis [39] which used to combine metal NPs into OSCs.

Table 1 shows short circuit current density; Jsc, current and generation rate for different position of Au NPs with diameter 30nm. It is clear that in this device structure we have optical parameters enhancement compare with previous works [38].

\begin{tabular}{cccc}
\hline OSC type & Jsc $\frac{m A}{c m^{2}}$ & Current A & Maximum generatin rate $\frac{1}{\frac{m^{3}}{s}}$ \\
& & & \\
\hline NPs are located at the active layer & 19.107 & $7.002 \times 10^{-11}$ & $3.577 \times 10^{28}$ \\
NPs are located at the highest part of AIL & 19.197 & $7.036 \times 10^{-11}$ & $1.662 \times 10^{29}$ \\
NPs are located at the middle part of AIL & 19.243 & $7.052 \times 10^{-11}$ & $1.986 \times 10^{29}$ \\
NPs are located at the lowest part of AIL & 19.665 & $7.207 \times 10^{-11}$ & $2.361 \times 10^{29}$ \\
Standard OSC & 19.007 & $6.966 \times 10^{-11}$ & $6.531 \times 10^{27}$
\end{tabular}

Table 1: OPV parameters for standard OSC and plasmonic OSC with different positions of NPs.

The generation rate is according to the following equation,

$$
G \sim P=\frac{1}{2} \varepsilon^{\prime \prime} \omega|E|^{2},
$$

where $\mathrm{G}$ is the exciton generation rate, $\mathrm{P}$ is the electromagnetic energy dissipation rate, $\varepsilon^{\prime \prime}$ is the imaginary part of complex permittivity, $\omega$ is the angular frequency of electromagnetic wave and $\mathrm{E}$ is the local electric field [40]. 
Fig. 1 shows the schematic drawing of standard polymer heterojunction solar cell. We have used Au nanospheres inside the active layer and AIL and have investigated the effect of the position of nanoparticles on efficiency enhancement of OSC with 3D FDTD simulation.

In Fig. 2 we can see the transmission spectrum of a standard OCS (without nanoparticles) and OSC with nanoparticles in different positions. We use Au NPs with diameter $30 \mathrm{~nm}$ inside the AIL with thickness $140 \mathrm{~nm}$. It seems that OSC with NPs are located at middle and highest part of AIL has maximum transmission.

Fig. 3 compares the power absorption of OSC in different modes. As can be seen, power absorption of OSC when the NPs are located in the lowest part of AIL for long wavelength; 635-750 nm, is greater than other.

\subsection{Silver (Ag) NPs located inside Anode interface layer}

Gold, silver, copper and aluminum are used in the photovoltaic devices as metallic nanoparticles because these metals can strongly interact with the sunlight [41]. Here we use $\mathrm{Ag}$ NPs with radius $30 \mathrm{~nm}$ inside the middle of AIL and compare the transmission and power absorption spectrum with $\mathrm{Au}$ NPs with 30nm radius. Fig. 4(a) illustrates the transmission spectrum of OSC with $\mathrm{Au}$ and Ag NPs. As we can see, approximately there is no difference between the transmission spectrum of OSC when Ag and Au NPs are located at AIL. In Fig 4 (b) it is clear that the power absorption spectrum of OSC for $\mathrm{Au} \mathrm{NPs}$ is more than Ag for the middle range of wavelength spectrum and these results agree with previous works [41].

\subsection{Variation of AIL thickness}

In this section we have changed the AIL thickness of standard OSC from $140 \mathrm{~nm}$ to 50 $\mathrm{nm}$ and have investigated the effect of thickness on light transmission, power absorption and other device parameters. As shown in Fig. 5(a) we can see the transmission spectrum for different thickness of AIL. It seems that the increase of thickness decreases the transmission for the wavelength between 300-630nm and for wavelength more than 630nm the rise of thickness causes the increase of light transmission. In Fig 5 (b) we can see the variations of power absoption in term of wavelength. The enhanced device parameters were obtained for different AIL thickness as shown in table 2.

\begin{tabular}{cccc}
\hline AIL thickness & Jsc $\frac{m A}{c^{2}}$ & Current A & Maximum generation rate $\frac{1}{\frac{m^{3}}{s}}$ \\
\hline $140 \mathrm{~nm}$ & 18.951 & $6.945 \times 10^{-11}$ & $6.530 \times 10^{27}$ \\
$100 \mathrm{~nm}$ & 18.384 & $6.737 \times 10^{-11}$ & $6.544 \times 10^{27}$ \\
$50 \mathrm{~nm}$ & 17.641 & $6.465 \times 10^{-11}$ & $6.809 \times 10^{27}$
\end{tabular}

Table 2: OPV parameters with variation of AIL thickness. 


\section{Conclusions}

In this work we investigated the role of NPs position in the optical parameters of OSC and found that the position of NPs in the AIL and active layer is an important factor which modifies the optical parameters of OSC. We also compared the light transmission and power absorption spectrum for $\mathrm{Au}$ and $\mathrm{Ag}$ nanoparticles when they are located in the middle of AIL and found that the absorption spectrum of Au NPs is greater than Ag

for the visible wavelength thus they are appropriate for the visible spectrum. This study opens new aspect in OSCs for light management.

\section{Declarations}

\section{$5.1 \quad$ Funding}

Not applicable

\subsection{Conflicts of interest/Competing interests}

Not applicable

\subsection{Availability of data and material}

Available

\subsection{Code availability}

Not applicable

\subsection{Authors' contributions}

Not applicable

\subsection{Ethics approval}

We believe that this manuscript is appropriate for publication by Plasmonics journal because it creates a paradigm for future studies. This manuscript has not been published and is not under consideration for publication elsewhere.

\subsection{Consent to participate}

Not applicable

\subsection{Consent for publication}

I give my consent for the publication of this manuscript which includes tables and figures in the Plasmonics journal. 


\section{References}

[1] Li G, Zhu R, Yang Y (2012) Polymer solar cells. Nat. Photon. 6:153-161.

[2] Liu M, Johnston MB, Snaith HJ (2013) Efficient planar heterojunction perovskite solar cells by vapour deposition. Nat. 501:395-398.

[3] Mathew S, Yella A, Gao P, Humphry-Baker R, Curchod BFE, Ashari-Astani N, Tavernelli I, Rothlisberger U, Nazeeruddin MK, Grtzel M (2014) Dye-sensitized solar cells with $13 \%$ efficiency achieved through the molecular engineering of porphyrin sensitizers. Nat. Chem. 6:242-247.

[4] Chuang CHM, Bulovic PRV, Bawendi MG (2014) Improved performance and stability in quantum dot solar cells through band alignment engineering. Nat. Mater. 13:796-801.

[5] Gnes S, Sariciftci HNS (2007) Conjugated Polymer-Based Organic Solar Cells. Chem. Rev. 107:1324-1338.

[6] Hösel M, Angmo D, S $\phi$ ndergaard RR, dos Reis Benatto GA, Carlé JE, Jrgensen M, Krebs FC (2014) High-Volume Processed, ITO-Free Superstrates and Substrates for Roll-to-Roll Development of Organic Electronics. Adv. Sci. 1:1400002-1-1400002-12.

[7] Cheng P, Bai H, Zawacka NK, Andersen TR, Liu W, Bundgaard E, Jrgensen M, Chen H, Krebs FC, Zhan X (2015) Roll-Coated Fabrication of Fullerene-Free Organic Solar Cells with Improved Stability. Adv. Sci. 2:1500096-1-1500096-6.

[8] Green MA, Emery K, Hishikawa Y, Warta W, Dunlop ED (2015) Solar cell efficiency tables (Version 45) Prog Photovolt Res Appl. 23:1-9.

[9] You J, Dou L, Yoshimura K, Kato T, Ohya K, Moriarty T, Emery K, Chen CC, Gao J, Li G (2013) A polymer tandem solar cell with $10.6 \%$ power conversion efficiency. Nat. Commun. 4:1446-1-1446-10.

[10] Wu JL, Chen FC, Hsiao YS, Chien FC, Chen P, Kuo CH, Huang MH, Hsu CS (2011) Surface plasmonic effects of metallic nanoparticles on the performance of polymer bulk heterojunction solar cells. ACS Nano 5:959-967.

[11] Wu J, Wang ZM (2014) Quantum Dot Solar Cells. Springer, New York.

[12] Ahmadi N (2020) Comparative study of the electronelectron interactions on optoelectronic properties of carbon nanotube within orthogonal and nonorthogonal tightbinding model. Optik 224:165654-1-11.

[13] Ahmadi N, Shokri AA (2017) Optoelectronic properties of silicon hexagonal nanotubes under an axial magnetic field. Opt. commun. 395:282288.

[14] Ahmadi, N (2018) Optoelectronic properties of silicon nanotubes with electronelectron interactions in orthogonal tight-binding model. Optik 170:436-443. 
[15] Wu J, Yu P, Susha AS, Sablon KA, Chen H, Zhou Z, Li H, Ji H, Niu X, Govorov AO, Rogach AL, Wang ZM (2015) Broadband efficiency enhancement in quantum dot solar cells coupled with multispiked plasmonic nanostars. Nano Energy 13:827-835.

[16] Yu P, Yao Y, Wu J, Niu X, Rogach AL, Wang Z (2017) Effects of Plasmonic Metal Core-Dielectric Shell Nanoparticles on the Broadband Light Absorption Enhancement in Thin Film Solar Cells. Sci. Rep. 7:7696-1-7696-10.

[17] Baek SW, Park G, Noh J, Cho C, Lee CH, Seo MK, Song H, Lee JY (2014) Au@ Ag coreshell nanocubes for efficient plasmonic light scattering effect in low bandgap organic solar cells. ACS Nano 8:3302-3312.

[18] Ahmadi N Efficiency enhancement in thin film silicon solar cells by plasmonic nanodisk arrays, is to be submitted in J. Nanophotonics.

[19] Johnson PB, Christy RW (1972) Optical constants of the noble metals, Phys. Rev. B 6:4370-4379.

[20] Haynes WM (2014) CRC Handbook of Chemistry and Physics, Boca Raton, CRC press.

[21] Huang J, Yin ZG, Zheng QD (2011) Applications of ZnO in organic and hybrid solar cells. Energy Environ. Sci. 4:3861-3877.

[22] Stelling C, Singh CR, Karg M, Knig TAF, Thelakkat M, Retsch M (2017) Plasmonic nanomeshes: their ambivalent role as transparent electrodes in organic solar cells. Sci. Rep. 7:42530-1- 42530-13.

[23] Moerland RJ, Hoogenboom JP (2016) Subnanometer-accuracy optical distance ruler based on fluorescence quenching by transparent conductors. Optica 3:112-117.

[24] Chen CW, Hsiao SY, Chen CY, Kang HW, Huang ZY, Lin HW (2015) Optical properties of organometal halide perovskite thin films and general device structure design rules for perovskite single and tandem solar cells. J. Mater Chem. A 3:91529159.

[25] Lee W, Chuang S, Chen H, Su W, Lin C (2010) Exploiting optical properties of P3HT: PCBM films for organic solar cells with semitransparent anode. Thin Solid Films 518:7450-7454.

[26] Kang MG, Xu T, Park HJ, Luo X, Jay Guo L (2010) Efficiency enhancement of organic solar cells using transparent plasmonic Ag nanowire electrodes. Adv. Mater. 22:4378-4383.

[27] Mariani G, Laghumavarapu RB, Tremolet De Villers B, Shapiro J, Senanayake P, Lin A, Schwartz BJ, Huffaker DL (2010) Hybrid conjugated polymer solar cells using patterned GaAs nanopillars. Appl. Phys. Lett. 97:013107-013113.

[28] Zeng B, Gan Q, Kafafi ZH, Bartoli FJ (2013) Polymeric photovoltaics with various metallic plasmonic nanostructures. J. Appl. Phys. 113:063109-063110. 
[29] Lindquist NC, Luhman WA, Oh SH, Holmes RJ (2008) Plasmonic nanocavity arrays for enhanced efficiency in organic photovoltaic cells. Appl. Phys. Lett. 93, 123308123313.

[30] Niggemann M, Glatthaar M, Gombert A, Hinsch A, Wittwer V (2004) Diffraction gratings and buried nano-electrodesarchitectures for organic solar cells. Thin Solid Films. 451-452:619-623.

[31] Lu L, Luo Z, Xu T, Yu L (2012) Cooperative plasmonic effect of Ag and Au nanoparticles on enhancing performance of polymer solar cells. Nano Lett. 13:59-64.

[32] Li X, Choy WCH, Huo L, Xie F, Sha WEI, Ding B, Guo X, Li Y, Hou J, You J, Yang Y (2012) Dual plasmonic nanostructures for high performance inverted organic solar cells. Adv. Mater. 24:3046-3052.

[33] Atwater HA, Polman A (2010) Plasmonics for improved photovoltaic devices. Nat. Mater. 9:205-213.

[34] Lu L, Luo Z, Xu T, Yu L (2013) Cooperative plasmonic effect of Ag and Au nanoparticles on enhancing performance of polymer solar cells. Nano Lett. 13:59-64.

[35] Choi H, Lee JP, Ko SJ, Jung JW, Park H, Yoo S, Park O, Jeong JR, Park S, Kim JY (2013) Multipositional silicacoated silver nanoparticles for high-performance polymer solar cells. Nano Lett. 13:2204-2208.

[36] Kim SS, Na SI, Jo J, Kim DY, Nah YC (2008) Plasmon enhanced performance of organic solar cells using electrodeposited Ag nanoparticles. Appl. Phys. Lett. 93:0733071-073307-3.

[37] Morfa AJ, Rowlen KL, Reilly TH, Romero MJ, van de Lagemaat J (2008) Plasmonenhanced solar energy conversion in organic bulk heterojunction photovoltaics. Appl. Phys. Lett. 92:013504-1- 013504-3.

[38] Xia R, Brabec CJ, Yip HL, Cao Y (2019) High-Throughput Optical Screening for Efficient Semitransparent Organic Solar Cells. Joule 3:2241-2254.

[39] Ng A, Yiu WK, Foo Y, Shen Q, Bejaoui A, Zhao Y, Gokkaya HC, Djurišić AB, Zapien GA, Chan WK, Surya C (2014) Enhanced performance of PTB7:PC(7)(1) BM solar cells via different morphologies of gold nanoparticles. ACS Appl. Mater. Interfaces 6:20676-20684 .

[40] Ahn S, Rourke D, Park W (2016) Plasmonic nanostructures for organic photovoltaic devices. J. Opt. 18:033001-1-033001-24.

[41] Catchpole KR, Polman A (2008) Design principles for particle plasmon enhanced solar cells. Appl. Phys. Lett. 93:191113-191123. 
Figure 1: Schematic drawing of organic solar cell.

Figure 2: Light transmission of organic solar cell with Au nanoparticles embedded in different positions of PEDOT:PSS and standard organic solar cell.

Figure 3: Power absorption of organic solar cell with $\mathrm{Au}$ nanoparticles embedded in different positions of PEDOT:PSS and standard organic solar cell.

Figure 4: (a) Light transmission (b) Power absorption of organic solar cell with Au and Ag nanoparticles embedded in the middle part of PEDOT:PSS.

Figure 5: (a) Light transmission (b) Power absorption of organic solar cell with different thickness of PEDOT:PSS. 
Figures

\section{Figure 1}

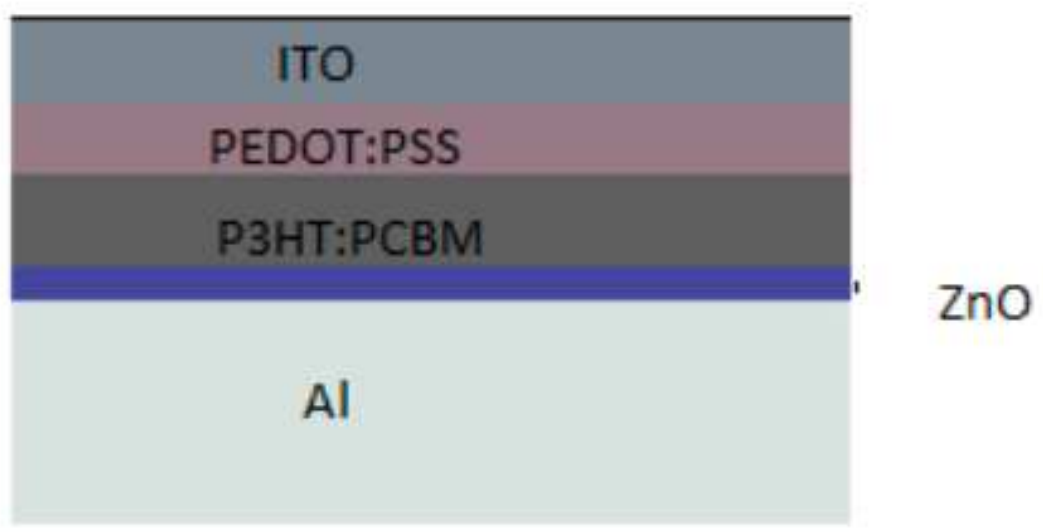

Figure 1

Schematic drawing of organic solar cell. 
Figure 2

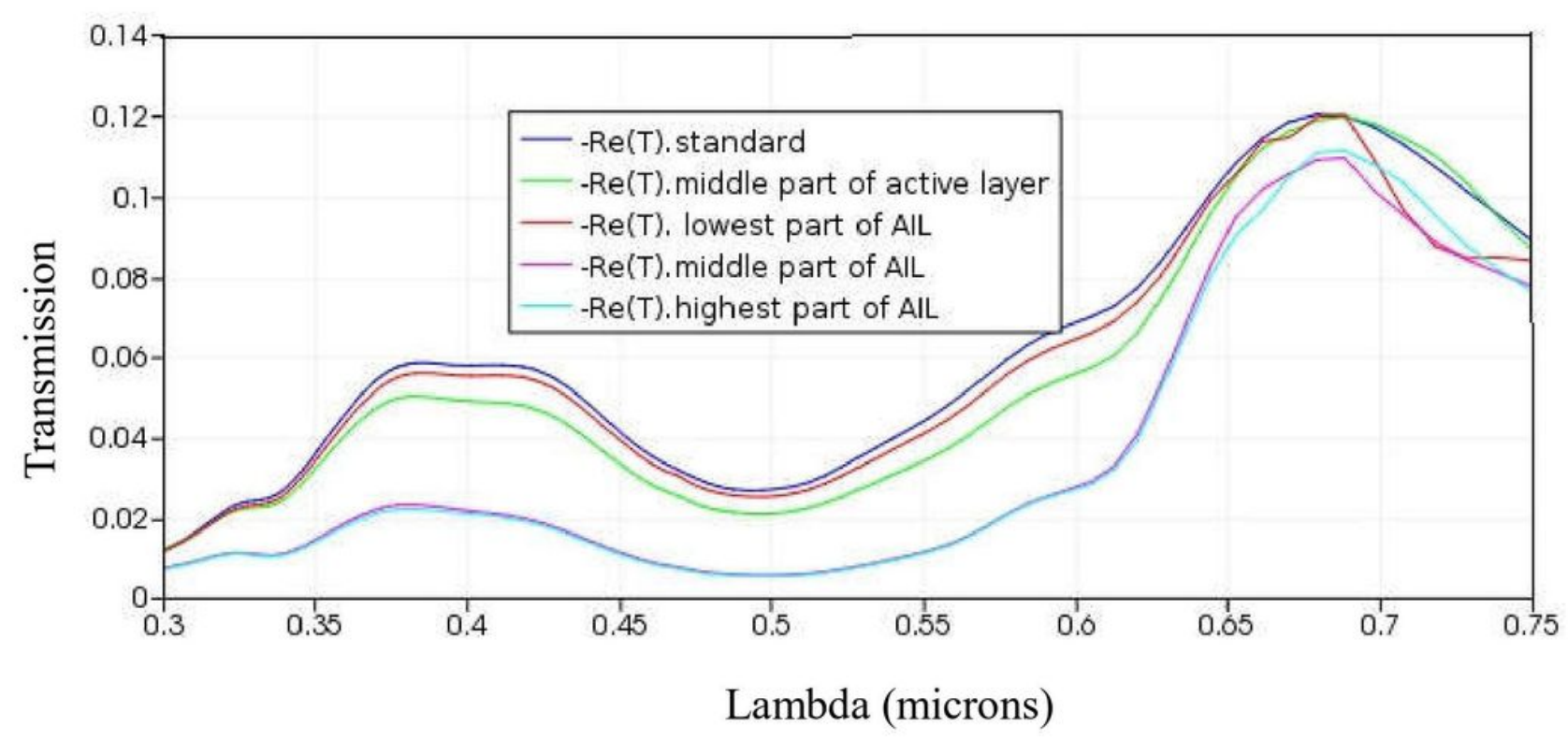

Figure 2

Light transmission of organic solar cell with Au nanoparticles embedded in different positions of PEDOT:PSS and standard organic solar cell. 
Figure 3

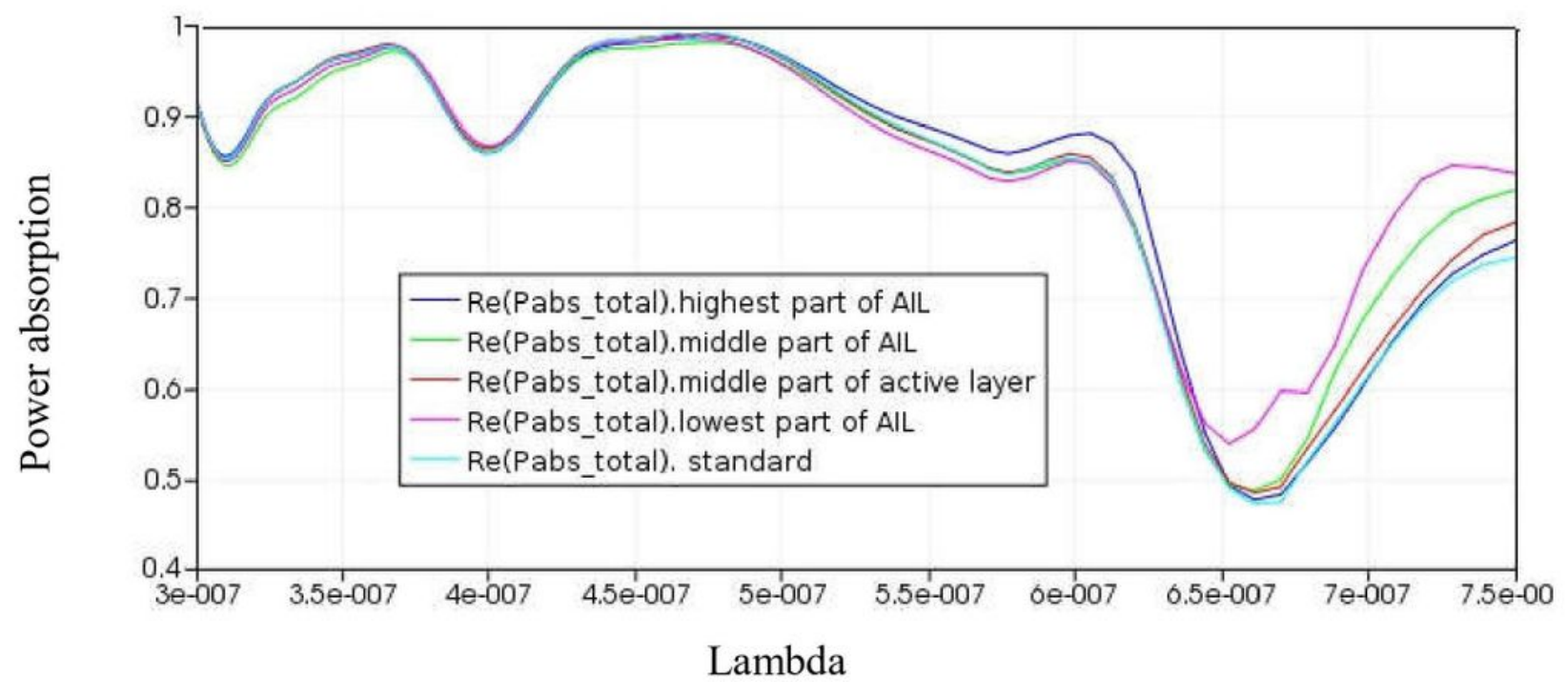

Figure 3

Power absorption of organic solar cell with Au nanoparticles embedded in different positions of PEDOT:PSS and standard organic solar cell. 
Figure 4

a

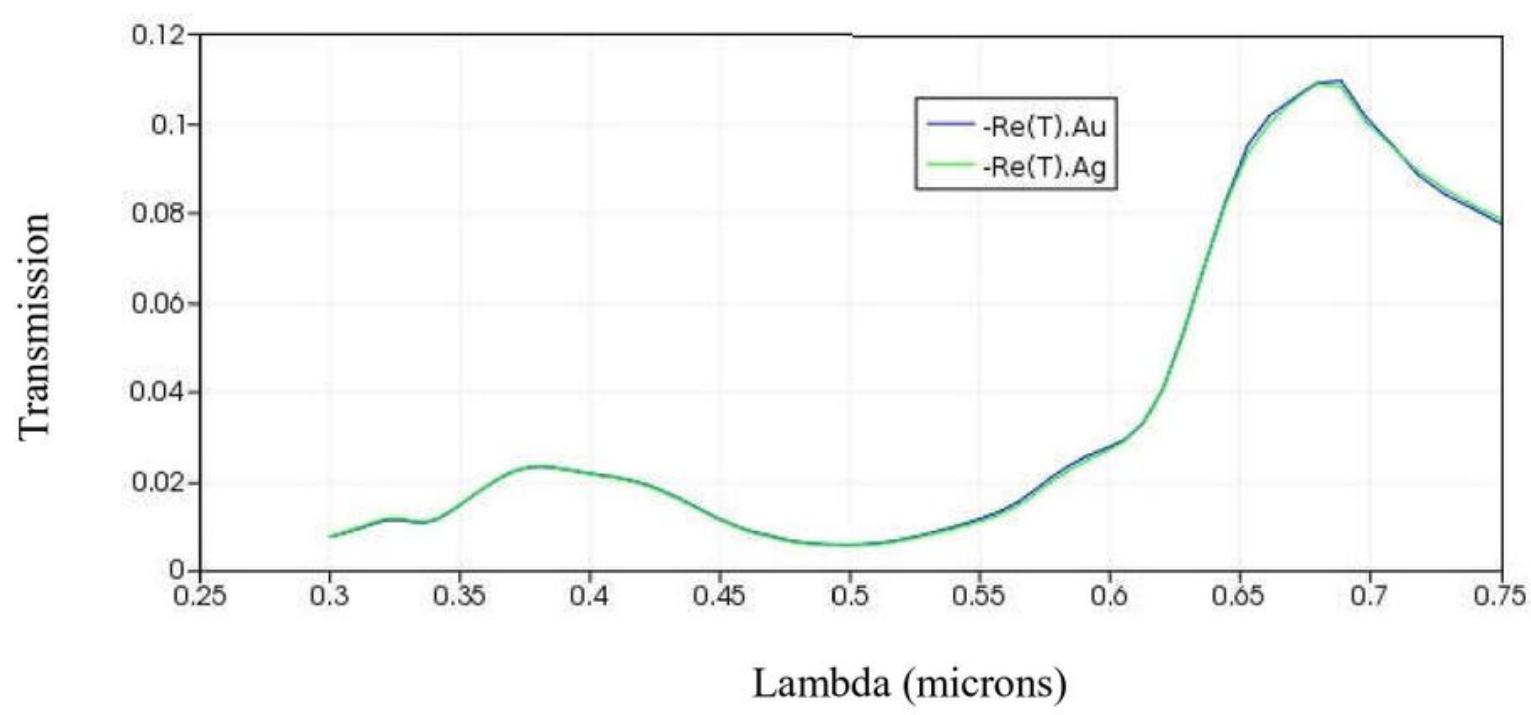

b

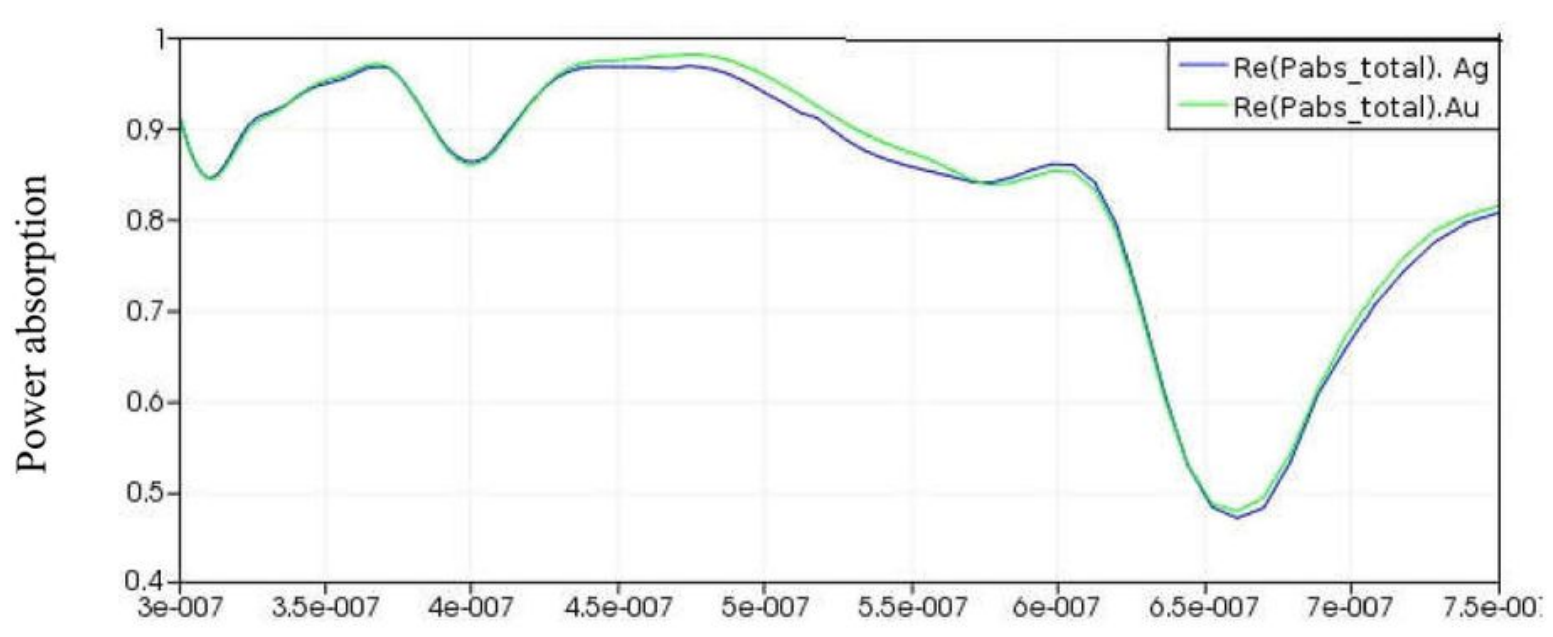

Lambda

\section{Figure 4}

(a) Light transmission (b) Power absorption of organic solar cell with Au and Ag nanoparticles embedded in the middle part of PEDOT:PSS. 
Figure 5

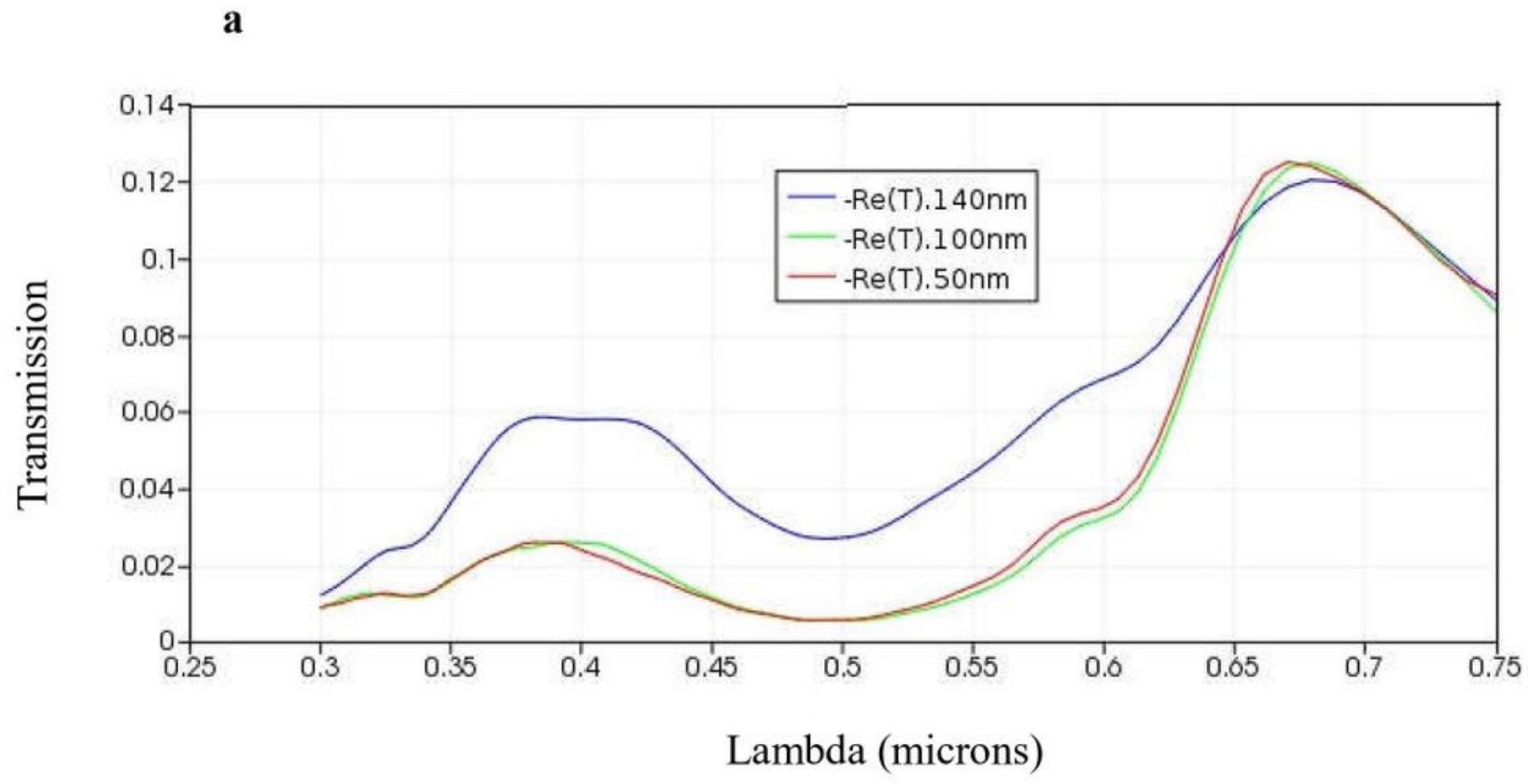

b

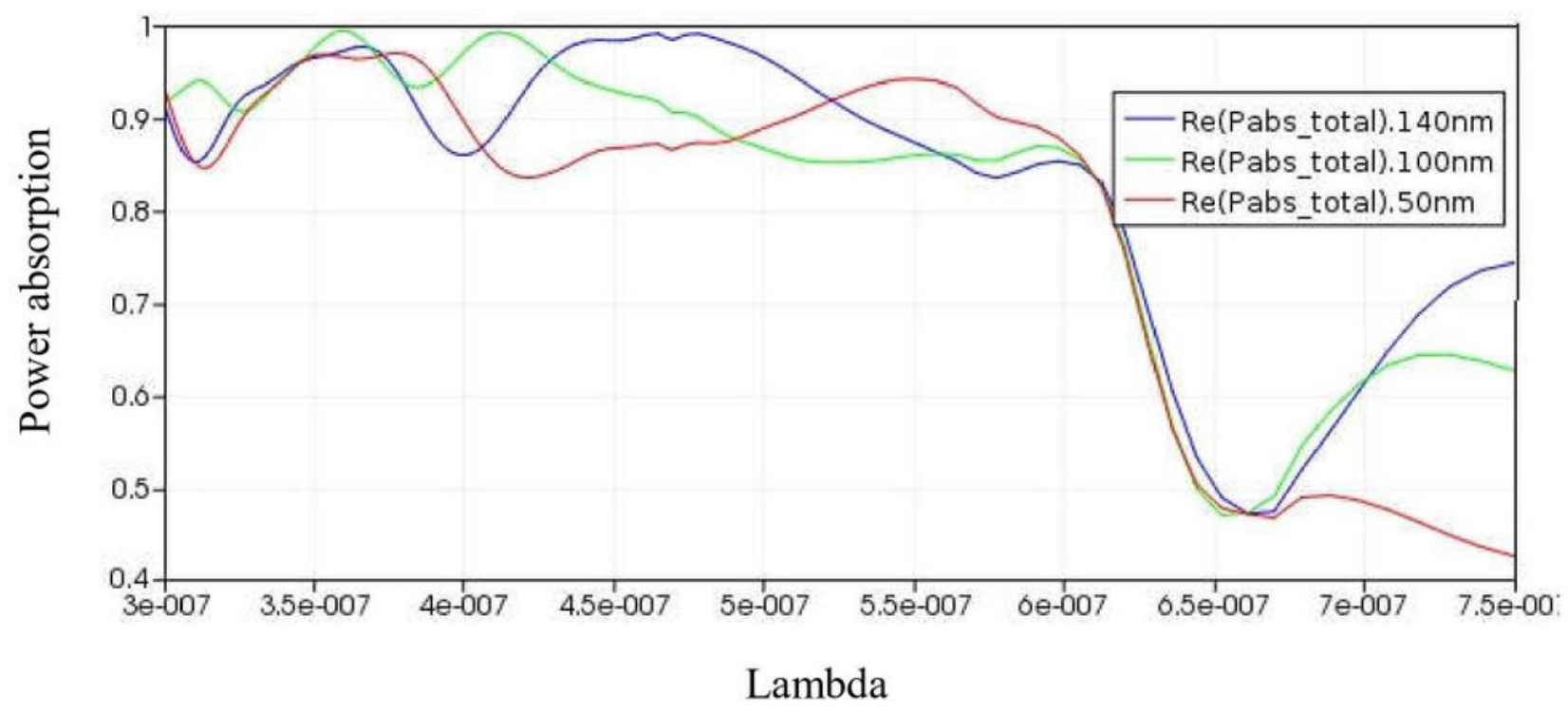

Figure 5

(a) Light transmission (b) Power absorption of organic solar cell with different thickness of PEDOT:PSS. 